\title{
DOLOMITE EXSOLUTION TEXTURES IN CALCITE FROM THE SIILINJÄRVI CARBONATITE COMPLEX, FINLAND
}

\author{
Kauko Puustinen
}

\begin{abstract}
Puustinen, Kauko 1974: Dolomite exsolution textures in calcite from the Siilinjärvi carbonatite complex, Finland. Bull. Geol. Soc. Finland 46, 151-159.

Lamellar, bleb-like and myrmekitic dolomite-calcite intergrowths have been observed in the carbonate rocks of the Silinjärvi carbonatite complex, Finland. Textures are the result of exsolution of dolomite from a magnesian calcite. Replacement of calcite by dolomite is rare within the complex. The calcites contain on an average $1.45 \% \mathrm{MgO}$. The composition of the coexisting dolomite-calcite pairs corresponds to a minimum equilibration temperature of $450^{\circ} \mathrm{C} . \mathrm{Fe}$ and $\mathrm{Mn}$ are enriched in the dolomites, $\mathrm{Sr}$ and $\mathrm{Ba}$ in the calcites.
\end{abstract}

Kauko Puustinen, Geological Survey of Finland, SF-02150 Otaniemi, Finland.

\section{Introduction}

The principal rock-forming carbonate minerals lie within the system $\mathrm{CaO}-\mathrm{MgO}-\mathrm{FeO}-\mathrm{MnO}-$ $\mathrm{CO}_{2}$. Subsolidus phase relations in the most important pair, $\mathrm{CaCO}_{3}-\mathrm{MgCO}_{3}$, have been investigated by Goldsmith and Newton (1969) as well as Goldsmith and Heard (1961). In the following, this part of the system is examined to explain the dolomite-calcite intergrowths.

Complete solid solubility occurs between calcite and dolomite at temperatures above $1075^{\circ} \mathrm{C}$. At lower temperatures, the solvus outlines a two-phase field in which a magnesian calcite is in equilibrium with dolomite. Below the solvus curve, the equilibrium is maintained through exsolution of dolomite from magnesian calcite. At $500^{\circ} \mathrm{C}$ a maximum of approximately $5 \mathrm{~mol}$ \% $\mathrm{MgCO}_{3}$ is soluble in the calcite structure, and the solvus goes through $16 \mathrm{~mol} . \%$ at $800^{\circ} \mathrm{C}$. At the same temperatures, only approximately 0.5 and 2 mol. $\% \mathrm{CaCO}_{3}$ can enter the dolomite structure.

The calcite-dolomite solvus has been used as a geological thermometer. The effect of total pressure has been assumed to be insignificant. Goldsmith and Newton (1969) have found that the temperature error produced by the pressure effect would not exceed $15^{\circ} \mathrm{C}$ in the range of 0 -10 kb. Experimental petrology has shown that carbonatitic magma can exist at temperatures of $638-450^{\circ} \mathrm{C}$ at pressures of $1000-10$ bars (Heinrich 1966).

This paper describes the dolomite-calcite relationship found in the carbonate-rich rocks of the Precambrian Siilinjärvi carbonatite complex in eastern Finland. The general geology has been previously dealt with by Puustinen (1971), and the mineralogy of the amphiboles and phlogopite by the same author (1972, 1973). 
The sequence of intrusion began with an ultramafic phase (glimmerite), consisting of phlogopite, amphibole and apatite with some accessory calcite, followed by the intrusion of syenite and the carbonatite proper. The carbonatitic phase (sövite) is composed of calcite with phlogopite, amphibole, apatite and dolomite as accessory minerals. These rocks are white, gray or pink in color, and generally medium-grained. Pure calcite crystals measuring up to some centimeters across have also been found without any exsolved dolomite. The pink calcite varieties show a reddish fluorescence in ultraviolet light. Dolomite, excluding the exsolution intergrowths in calcite, has not been found in large quantities. The sövite was emplaced into the pre-existing ultramafic rocks, probably in the form of dikes. The sövite and the glimmerite form a series of hybric rocks.

\section{Textures}

At Siilinjärvi, the observed exsolution textures of dolomite in the host calcite occur in the form of lamellae, blebs of various shapes and myrmekite (Fig. 1). In this paper, the term myrmekite is used to describe a worm-like texture. In some cases, also veins and replacement textures have been found. Some 60 samples were investigated

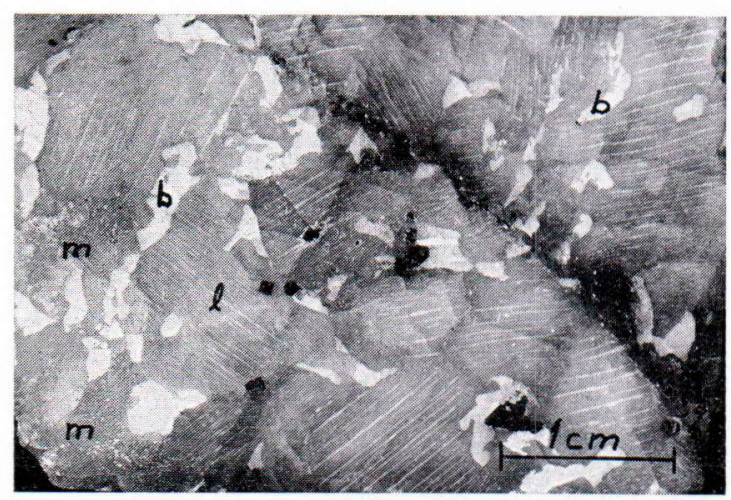

Fig. 1. Exsolution lamellae (1), large blebs (b) at grain boundaries and myrmekite (m) of dolomite in calcite. Carbonatite, Lake Saarinen. Specimen (No. R71-109.61) stained with alizarine red S solution. in the course of this work. No dolomite-calcite intergrowths were found in 11 samples representing entirely pure sövites. Lamellar textures occur mainly in connection with white-colored calcite-bearing rocks.

In the study of carbonate rocks, staining facilitates the identification of the main carbonate minerals. The most suitable method to distinguish calcite from dolomite is to immerse the samples in alizarine red $\mathrm{S}$ solution and allow them to react for $30-60$ seconds. Calcite is stained a deep red, while dolomite is not affected by the solution.

The rock samples were first cut with a diamond saw, and then ground to obtain a smooth plane for macroscopic observations. Thin sections and polished sections were prepared from selected samples, and stained with the alizarine red $\mathrm{S}$ solution. The best results were obtained from polished sections that were first immersed for five seconds in an $0.25 \%$ acetic acid solution and then stained with the alizarine red $\mathrm{S}$ solution.

The nucleation, growth and type of an exsolution texture depends initially on the magnesium concentration of the carbonate solid solution. Dolomite intergrowth are absent from some samples, but the chemical composition of a homogeneous calcite is similar to a calcite associated with exsolution products ( $c f$. Table 1). The physical conditions govern the course of the exsolution process. This complex mechanism of the subsequent growth of exsolving particles differs from sample to sample and from crystal to crystal within the same sample.

The size of the exsolved particles depends on the grain size of the rock, fine-grained varieties showing usually little or no exsolved dolomite. The particle size ranges from microscopic dimensions to several centimeters in diameter in the Siilinjärvi complex. A particular exsolution texture cannot be correlated to any specific rock type.

In general, the way an exsolving phase always grows is that the sum of the energies of elastic strain and surface tends towards a minimum. Because the elastic strain energy is much less for a plate than for a sphere of equal volume, a coherent texture (a lattice continuity exists across the interface between the exsolving phase 
and the host phase) results in the initial exsolution stage, as found by Brett (1964).

At Siilinjärvi, coherent lamellae are found to be up to $0.4 \mathrm{~mm}$ wide and $10 \mathrm{~mm}$ in length in the form of lens-like plates. Fig. 2 shows a dense and thin lamellar texture ( $c f$. also Puustinen 1971, Fig. 9). The size of the smallest lamellae is below the resolving power of the microscope. Small and relatively wide lamellae are called rods (Fig. 3). The lamellae always run parallel in the same host calcite crystal.

The exsolution process begins with the formation of rods, which grow and coalesce. If the nucleation is irregularly distributed, relatively long lamellae and short rods are apt to grow in different parts of the same calcite crystal. The rods, as observed in thin sections, are also in some instances cross sections of lamellae in other grains. As the exsolution proceeds by the thickening of a coherent lamella, the elastic strain energy becomes greater than the surface energy, and the lamellae are apt to break noncoherently or widen to a bleb (Figs. 4 and 5).

If the concentration of the exsolving magnesian phase is sufficient, the dolomite lamellae grow through the entire host calcite crystal, forming a laminated texture. In such cases, the lamellae, which are up to $20 \mathrm{~mm}$ long, have a ragged interface against the calcite (Fig. 6). Small blebs are found inside calcite »layers». Either this laminated texture ends at the crystal boundary, or the excess of the exsolving dolomite phase continues to grow at the boundaries of the calcite grains as irregular patches.

A reverse pairing of the host dolomite with calcite veinlets has been found in samples containing more dolomite than calcite. Now the interface conforms to the rhombohedral crystal faces of carbonate minerals as in the laminated texture. Small calcite islands or lamellae are distributed in the host dolomite, resembling the antiperthite texture of feldspars. This texture has been reported as occurring in the Söve carbonatite of Norway (van der Veen 1965) and

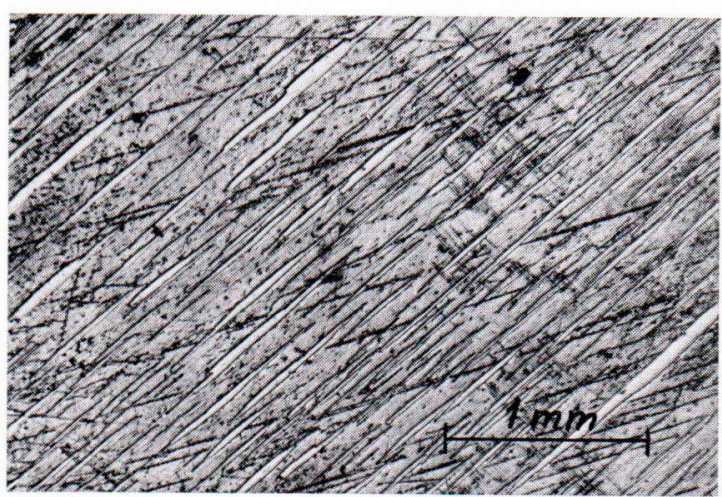

Fig. 2. Coherent exsolution lamellae of dolomite in calcite. Carbonate glimmerite, Lake Saarinen. Stained polished section (No. R67-38.00).

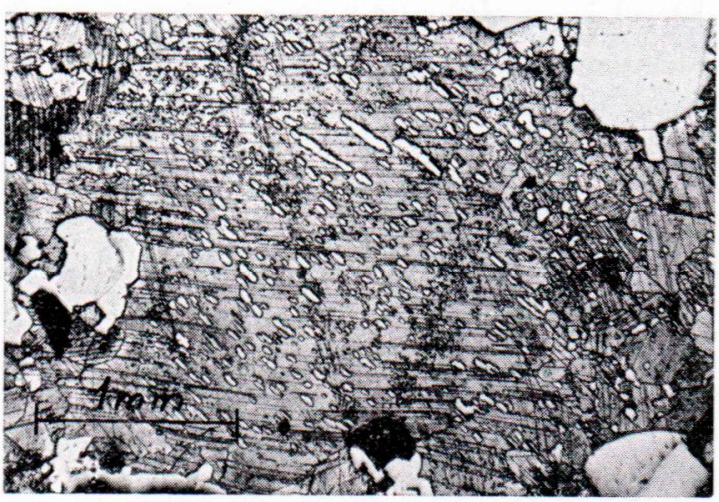

Fig. 3. Exsolution rods of dolomite in calcite. Mica peridotite, northwest of Lake Pahkalampi. Stained polished section (No. R26-256.78).

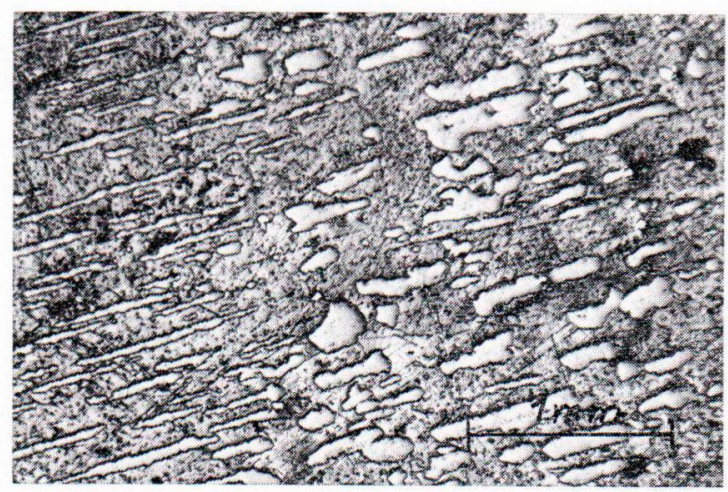

Fig. 4. »Semi-coherent» exsolution lamellae of dolomite in calcite. Carbonate glimmerite, Lake Saarinen. Stained polished section (No. R67-38.00). 


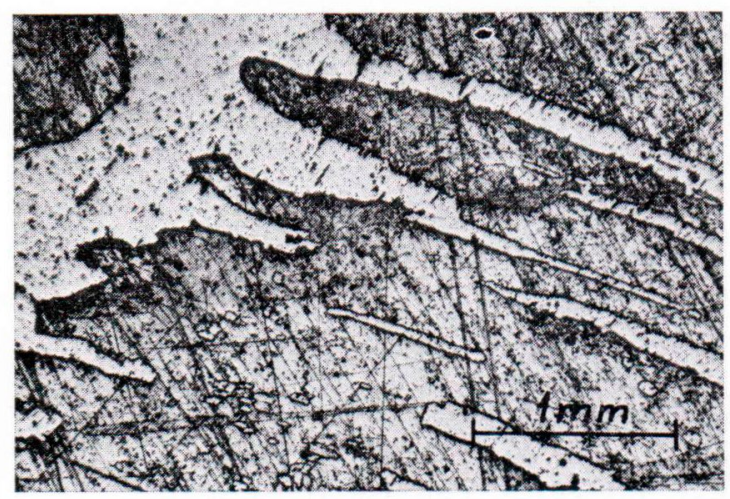

Fig. 5. Exsolution »comb» of dolomite in calcite. Carbonatite, Lake Saarinen. Stained polished section (No. R67-29.68).

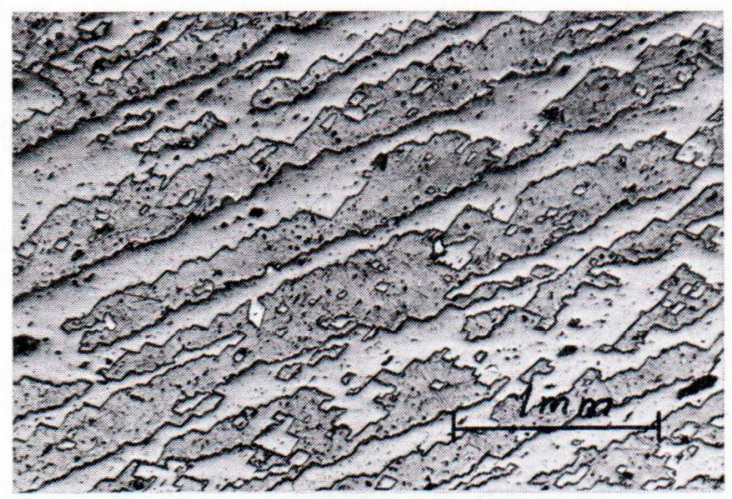

Fig. 6. Laminated exsolution texture of dolomite (white) in calcite (gray). Magnetite-bearing carbonatite, Lake Saarinen. Stained polished section (No. R67-22.80).

in Ngualla, Tanzania, as well as Iron Hill, Colorado (Heinrich 1966).

Depending on different physical conditions a bleb texture of drops or more irregular particles may grow in the host calcite (Fig. 7). The exsolution begins with the formation of relatively evenly distributed drops, measuring up to $0.5 \mathrm{~mm}$ in diameter. The drops have a tendency to grow and coalesce, the resulting texture being in some instances quite complex.

As in the lamellar texture, the excess of the exsolving dolomite material, which does no remain in the calcite crystal, is deposited at the boundaries of calcite grains. These irregular particles may range in size up to $10 \mathrm{~mm}$ (Fig. 1).

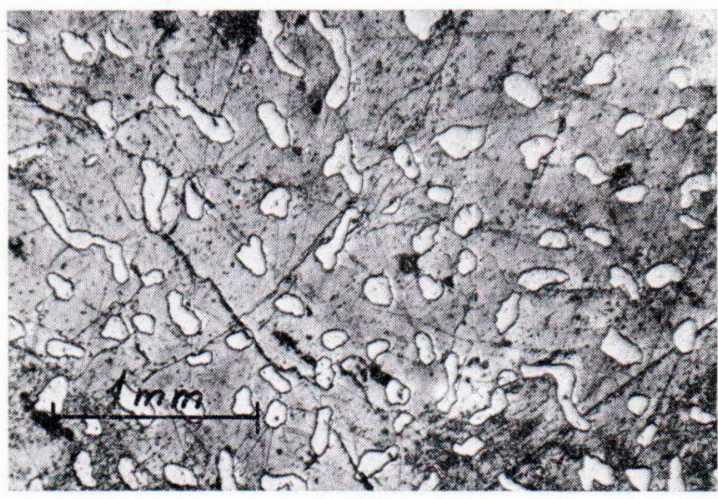

Fig. 7. Exsolution blebs of dolomite in calcite. Carbonate glimmerite, Lake Saarinen. Stained polished section (No. R67-38.00).

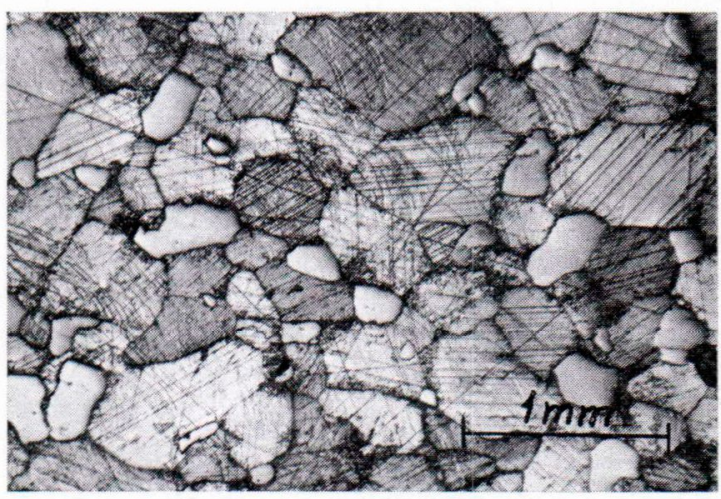

Fig. 8. Exsolution blebs of dolomite at calcite grain boundaries. Carbonatite, Lake Särkilampi. Stained polished section (No. 57/KP-67).

In some fine-grained rock varieties, all the exsolved dolomite has migrated outside the host crystal to the grain boundaries, the resulting texture having a polygonal appearence (Fig. 8).

Myrmekitic vermicules and embays of dolomite have been formed by the coalescence of rods, lamellae and blebs (Fig. 9). Series leading from simple textures to myrmekite have been observed.

Very fine-grained, cloudy features are occasionally observed between the dolomite exsolution intergrowths in the host calcite. These also seem to be dolomite exsolution particles, possibly belonging to another generation. This phenomenon can be related to the observations 


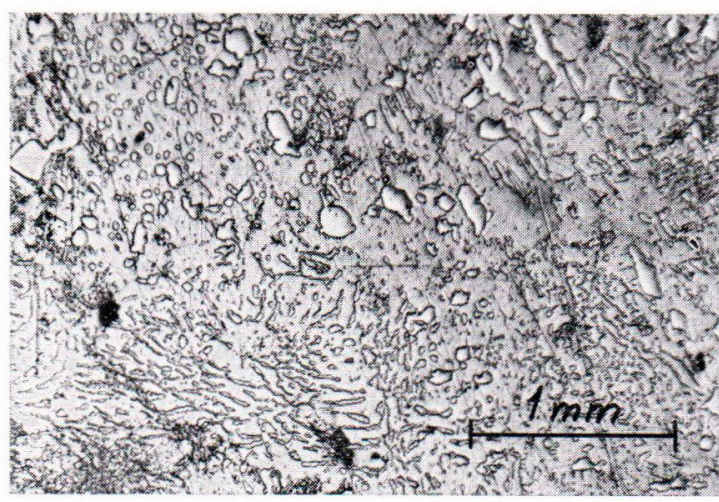

Fig. 9. Exsolution myrmekite and blebs of dolomite in calcite. Silicocarbonatite, Lake Saarinen. Stained polished section (No. R68-119.13).

reported by Ioffe (1972), who has found that calcites with exsolution features include several exsolution phases. In the light of X-ray patterns, these varieties suggest that in the process of exsolution by no means all natural magnesian calcites reach equilibrium. Brett (1964) regards an extremely fine-grained texture as indicating formation at low temperatures. Had the material been annealed at higher temperatures, the rates of diffusion would have been high enough to cause the coalescence of fine grains and produce a coarse-grained texture.

In addition to the exsolution features, dolomite veinlets have also been observed in the samples from Siilinjärvi. These seem to result from the squeezing of excess exsolved dolomite material into carbonate minerals. Replacement textures are found only in rocks in which the amount of dolomite exceeds that of calcite. In these cases, dolomite replaces the calcite along the cleavage planes.

\section{Chemical composition}

Table 1 shows the chemical composition of coexisting calcites and dolomites in the order of

TABLE 1

Chemical composition of coexisting calcites and dolomites from the Siilinjärvi carbonatite complex. Equilibration temperatures after graphs by Goldsmith and Newton (1969). Microprobe analyses by Jaakko Siivola

\begin{tabular}{|c|c|c|c|c|c|c|c|c|c|c|}
\hline \multirow{2}{*}{ Wt. \% } & \multicolumn{5}{|c|}{ Calcite } & \multicolumn{5}{|c|}{ Dolomite } \\
\hline & $\mathrm{FeO}$ & $\mathrm{MnO}$ & $\mathrm{MgO}$ & $\mathrm{CaO}$ & & $\mathrm{FeO}$ & $\mathrm{MnO}$ & $\mathrm{MgO}$ & $\mathrm{CaO}$ & Texture \\
\hline 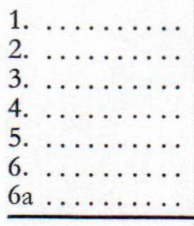 & $\begin{array}{l}0.4 \\
0.2 \\
0.3 \\
0.7 \\
0.6 \\
0.8\end{array}$ & $\begin{array}{l}0.2 \\
0.1 \\
0.1 \\
0.2 \\
0.1 \\
0.2\end{array}$ & $\begin{array}{l}0.7 \\
0.8 \\
0.8 \\
1.6 \\
1.8 \\
2.5\end{array}$ & $\begin{array}{l}53.5 \\
52.5 \\
52.6 \\
52.6 \\
52.8 \\
52.9\end{array}$ & & $\begin{array}{l}2.9 \\
2.0 \\
\\
2.7 \\
3.3 \\
2.6 \\
3.1 \\
\end{array}$ & $\begin{array}{l}0.3 \\
0.3 \\
\\
0.2 \\
0.4 \\
0.2 \\
0.2 \\
\end{array}$ & $\begin{array}{l}21.3 \\
19.5 \\
19.3 \\
17.1 \\
19.7 \\
19.2 \\
\end{array}$ & $\begin{array}{l}28.2 \\
30.7 \\
32.0 \\
31.3 \\
30.1 \\
28.2 \\
\end{array}$ & $\begin{array}{r}\mathrm{b} \\
\mathrm{r} \\
\mathrm{l} \\
\mathrm{b} \\
1 \\
\mathrm{~b}\end{array}$ \\
\hline Mol. \% & $\mathrm{FeCO}_{3}$ & $\mathrm{MnCO}_{3}$ & $\mathrm{MgCO}_{3}$ & $\mathrm{CaCO}_{3}$ & $\mathrm{~T}^{\circ} \mathrm{C}$ & $\mathrm{FeCO}_{3}$ & $\mathrm{MnCO}_{3}$ & $\mathrm{MgCO}_{3}$ & $\mathrm{CaCO}_{3}$ & \\
\hline 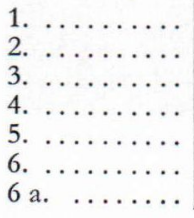 & $\begin{array}{l}0.5 \\
0.3 \\
0.4 \\
0.9 \\
0.8 \\
1.0\end{array}$ & $\begin{array}{l}0.3 \\
0.2 \\
0.2 \\
0.2 \\
0.2 \\
0.3\end{array}$ & $\begin{array}{l}1.6 \\
2.0 \\
2.0 \\
3.9 \\
4.5 \\
6.0\end{array}$ & $\begin{array}{l}97.6 \\
97.5 \\
97.4 \\
95.0 \\
94.5 \\
92.7\end{array}$ & $\begin{array}{l}350 \\
380 \\
380 \\
480 \\
500 \\
560\end{array}$ & $\begin{array}{l}3.7 \\
2.6 \\
\\
3.5 \\
4.4 \\
3.4 \\
4.2\end{array}$ & $\begin{array}{l}0.4 \\
0.3 \\
\\
0.2 \\
0.5 \\
0.3 \\
0.3\end{array}$ & $\begin{array}{l}49.1 \\
45.6 \\
43.9 \\
41.0 \\
45.9 \\
46.5\end{array}$ & $\begin{array}{l}46.8 \\
51.5 \\
\\
52.4 \\
54.1 \\
50.4 \\
49.1\end{array}$ & \\
\hline
\end{tabular}

1. From glimmerite, north of Lake Saarinen (Specimen No. R86-12.72).

2. From magnetite carbonatite, Lake Saarinen (Specimen No. R67-22.80).

3. From carbonatite, north of Lake Saarinen (Specimen No. R84-172.28).

4. From carbonatite, Lake Saarinen (Specimen No. R71-109.61).

5. From apatite carbonatite, Lake Särkilampi (Specimen No. 745).

6. From silicocarbonatite, Lake Saarinen (Specimen No. R67-31.36).

Textures: $1=$ lamellar, $\mathrm{b}=$ bleb-like, $\mathrm{r}=$ rhombohedral and $-=$ no exsolved dolomite. 
TABLE 2

Chemical composition of carbonates from the Siilinjärvi carbonatite complex according to Puustinen (1971). Model temperatures after graphs by Goldsmith and Newton (1969). Analyses by P. Ojanperä and V. Hoffrén (1-4 and 6) and International Minerals \& Chemical Corp. (5)

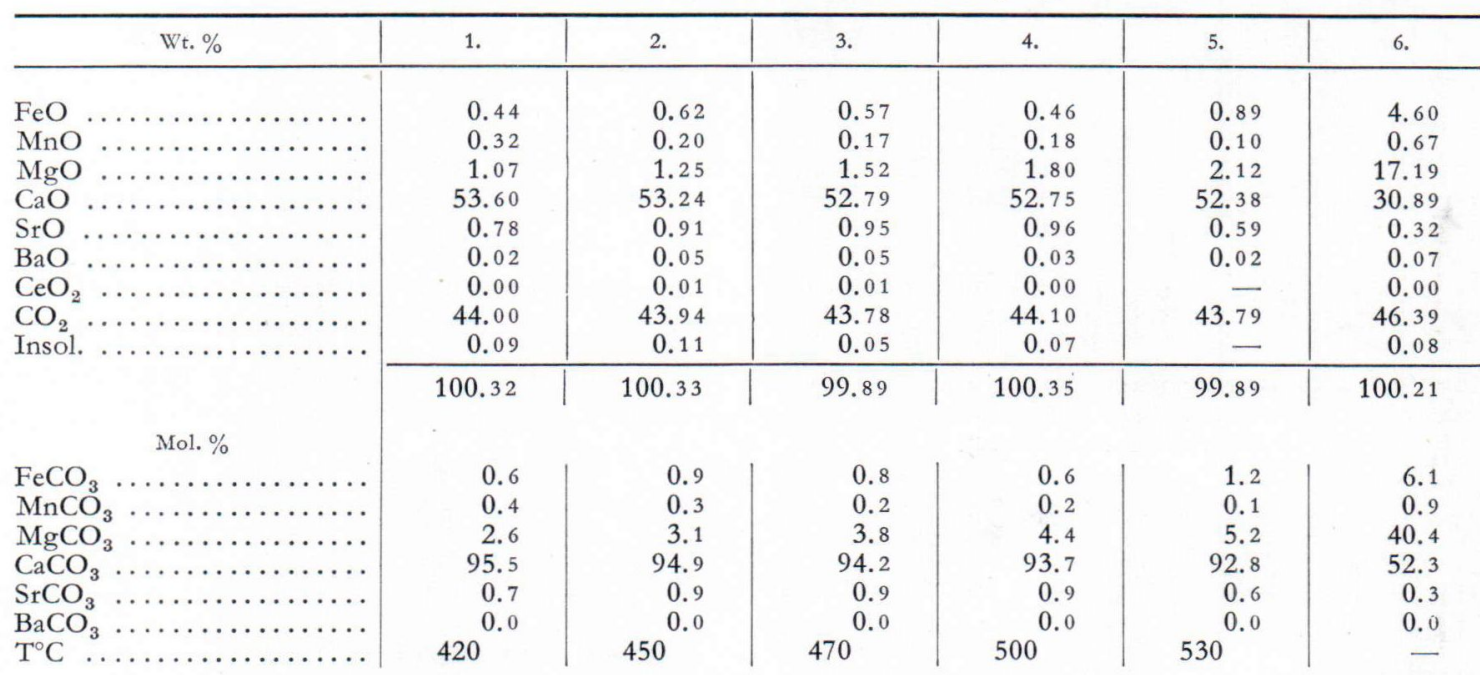

1. Calcite, reddish, from a vein in glimmerite, Lake Saarinen (Specimen No. 71-1/KP-67).

2. Calcite, fine-grained, from carbonatite, Lake Saarinen (Specimen No. 71-8/KP-67).

3. Calcite, coarse-grained, same specimen as in analysis 2.

4. Calcite from carbonate glimmerite, Lake Särkilampi (Specimen No. 85-1/KP-67).

5. Calcite from apatite carbonatite, Lake Särkilampi (Specimen No. FZ-44P).

6. Dolomite from silicocarbonatite, Lake Saarinen (Specimen No. R67-22.80).

decreasing molecular percentage of $\mathrm{CaCO}_{3}$. Analysis 2 is of a predominantly dolomitic sample with accessory calcite rhombohedrons (cf. Fig. 6). Analysis 3 is of a homogeneous calcite. A calcite sample containing both dolomite lamellae and blebs is presented as analyses 6 and $6 \mathrm{a}$. Other carbonate analyses from the Siilinjärvi complex, done by Puustinen (1971), are reproduced in Table 2, in which analysis 6 is of the same dolomite as analysis 2 in Table 1.

Electron microprobe tests showed that the $\mathrm{Fe}$ and $\mathrm{Mg}$ contents are nearly contant in different dolomite lamellae and in different parts of the same dolomite lamella. It was also found that $\mathrm{Sr}$ and $\mathrm{Ba}$ are enriched in the calcite phase. The distribution of $\mathrm{Mg}$ in a calcite sample with dolomite lamellae is shown in Fig. 10.

It can be concluded that $\mathrm{Fe}$ and $\mathrm{Mn}$ are enriched in dolomites, and that $\mathrm{Sr}$ as well as possibly also $\mathrm{Ba}$ and the rare-earth elements are

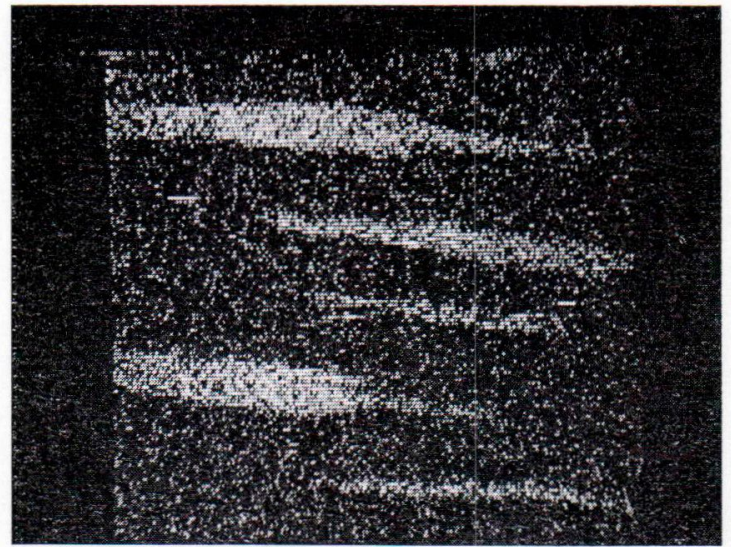

Fig. 10. Electron microprobe scanning picture showing the distribution of magnesium in exsolution lamellae of dolomite in calcite. Carbonatite, Lake Saarinen. Specimen No. R71-109.61, magn. 140 X.

enriched in calcites. In both the calcites and the dolomites there is a negative correlation between $\mathrm{Mg}$ and $\mathrm{Ca}$. A positive correlation exists between 
$\mathrm{Fe}$ and $\mathrm{Mg}$ in the calcites, and between $\mathrm{Fe}$ and $\mathrm{Mn}$ in the dolomites. On the other hand, a negative correlation prevails between $\mathrm{Fe}$ and $\mathrm{Ca}$ in the calcites. No clear difference has been observed between the chemical compositions of exsolved dolomite lamellae and blebs in the same sample. A homogeneous calcite has the same composition as occurrences containing exsolved dolomite. In general, the analyzed coexisting carbonates seem to be in equilibrium with each other. Dolomite analyses 6 and $6 \mathrm{a}$ in Table 1 represent, however, a metastable calcitedolomite pair. This sample is characterized by the presence of a highly varied texture with relatively large myrmekitic forms.

According to Quon and Heinrich (1966), the carbonatitic calcites are enriched in $\mathrm{Ba}, \mathrm{Sr}, \mathrm{Mn}$, $\mathrm{Mg}$ and $\mathrm{Ce}$ rare-earth elements compared with their sedimentary metamorphic counterparts. At Siilinjärvi, the $\mathrm{Ba}$ content is relatively low, but the $\mathrm{Sr}$ content is within the range of characteristic carbonatites. The calcites contain on an average $1.45 \% \mathrm{MgO}$, corresponding to about $3.6 \mathrm{~mol} \%$ $\mathrm{MgCO}_{3}$. Dolomites show in some cases excess $\mathrm{CaCO}_{3}$, which has been found, according to Goldsmith and Graf (1958), to be up to 5 mol. $\% \mathrm{CaCO}_{3}$ in natural dolomites.

The calcite-dolomite solvus has been used as a geological thermometer in petrological studies (Carpenter 1967). At Siilinjärvi, the calculated molecular percentages of $\mathrm{MgCO}_{3}$ of calcites in Table 1 indicate an average minimum equilibration temperature of about $450^{\circ} \mathrm{C}$. Temperatures obtained from pure calcite samples (Table 2) are slightly higher, averaging about $475^{\circ} \mathrm{C}$. In all the analyses, the iron content of calcites was also found to have a positive correlation with the obtained model temperatures.

\section{Discussion}

The textures formed when dolomite is exsolved from calcite are determined by the crystal structures of these minerals. The calcite structure is made up of alternating planes of $\mathrm{CO}_{3}$ groups and $\mathrm{Ca}$ atoms, perpendicular to the c-axis. The dolomite structure is a derivative of the calcite structure, in which alternate cation planes are made up of $\mathrm{Mg}$ atoms. Magnesian calcites are disordered with respect to $\mathrm{Ca}$ and $\mathrm{Mg}$. When a hightemperature magnesian calcite is cooled to the point where not all the $\mathrm{Mg}$ is stable in the calcite structure, dolomite is exsolved. Diffusion of $\mathrm{Ca}^{2+}$ and $\mathrm{Mg}^{2+}$ within the host calcite structure is all that is required for the segregation of $\mathrm{Mg}$ into specific planes. This explains the formation of the lamellar texture and the same crystallographic orientation with the host calcite, as verified by Goldsmith (1960) with X-ray singlecrystal techniques.

Generally, exsolution is effected by nucleation and the subsequent growth of exsolved particles in the previously homogeneous phase. The mechanism is complex, and it is influenced by the temperature, pressure, concentration, purity, structure and grain size of the solid solution, the coefficient of diffusion and the distribution of stress within the crystal. Nucleation is most easily achieved in the neighborhood of imperfections such as dislocations, twin lamellae and grain boundaries, because there the lattice has a free energy exceeding the average. After nucleation has occurred, the rate of growth of the exsolving phase depends on the rate of diffusion.

Exsolution textures of dolomite in host calcite in carbonate rocks have been observed in relatively many cases, especially in connection with a high-temperature environment. According to Graf and Goldsmith (1955), exsolution of dolomite from fine-grained synthetic magnesian calcites takes place also in the laboratory, at temperatures above approximately $500^{\circ} \mathrm{C}$.

Carpenter (1967) describes exsolution textures in the Crestmore (California) metamorphosed marble. A minimum temperature of $760-800^{\circ} \mathrm{C}$ at 700 bars $\mathrm{CO}_{2}$ pressure would have been required at the time of metamorphism. Examples of dolomite exsolutions in marbles have also been presented by Goldsmith and others (1955), and cited by Harker and Tuttle (1955). Ioffe and 
others (1973) have found that the Baykal (USSR) marbles were metamorphosed at temperatures of $580-740^{\circ} \mathrm{C}$.

Many carbonatites show exsolution textures of dolomite in calcite. However, Quon (1965) has found that these features are not particularly common. He hade attempts by staining to find examples in 25 carbonatite deposits and obtained negative results. However, positive results might have been attained through microscopic studies of polished sections.

In the Sangu (Tanzania) carbonatite, almost all the specimens studied by Coetzee (1963) contained a fine-grained myrmekitic carbonate matrix with grains of dolomite. The presence of the textures was considered to indicate that the rocks were not emplaced in the solid state by plastic flow, for otherwise these textures would have been destroyed.

These textures are dealt with by van der Veen (1965) as observed in the Panda Hill (Mbeya, Tanzania), Palabora (South Africa) and Söve (Norway) carbonatites. The observed lamellar, bleb-like, and myrmekitic textures are the result of the exsolution of dolomite from calcite. Kononova and Tarashchan (1970) regard the exsolution features as characteristic of early calcite carbonatites.

The $\mathrm{Mg}$ content of natural calcites from various environments has been investigated by Goldsmith and others (1955). Sedimentary calcites are low in $\mathrm{Mg}$, with the exception of certain metastable fossil materials. Metamorphic calcites commonly contain up to 9 mol. \% $\mathrm{MgCO}_{3}$ in solid solution. Graf and Goldsmith (1955) report that this substitution, if stable at the time of formation, corresponds to a temperature of about $600^{\circ} \mathrm{C}$, assuming that the $\mathrm{CO}_{2}$ pressure is high enough to prevent decomposition of the dolomite, and that there is a sufficient amount of $\mathrm{Mg}$ present to produce dolomite in equilibrium with the magnesian calcite. If carbonate rocks were thermally metamorphosed under conditions permitting the escape of $\mathrm{CO}_{2}$, the resulting calcite should be virtually free of $\mathrm{Mg}$. In the Siilinjärvi complex, the calcite always contains some $\mathrm{Mg}$ in solid solution. It is further noteworthy that the complex has not been affected by large-scale regional metamorphism. Goldsmith and others (1955) have found that recrystallization during or after the exsolution might produce independent grains of dolomite and calcite, so that many high-temperature marbles would contain no evidence of exsolution, even though it had taken place.

It has been found that the dolomite exsolutions from calcite are common in the carbonaterich rocks of the Silinjärvi carbonatite complex. The concentration of the intergrowths could not be related to any particular rock types. However, more complex structures seem to be common in magnetite and sulphide-bearing carbonatites around Lake Saarinen. In general, the bleb texture is the most common exsolution feature, but lamellar textures are also quite frequently seen. The character of the dolomite-calcite intergrowths is analogous to the observations within ore and silicate mineralogy, and the exsolution process is directly based on the phase relations in the system $\mathrm{CaO}-\mathrm{MgO}-\mathrm{CO}_{2}$.

Acknowledgments - The manuscript was critically read by Dr. Atso Vorma, the microprobe analyses were made by Dr. Jaakko Siivola, and the English was checked by Mr. Caj Kortman, Lic. Phil., all members of the staff of the Geological Survey of Finland. 


\section{REFERENCES}

Bretr, Robin (1964) Experimental data from the system $\mathrm{Cu}-\mathrm{Fe}-\mathrm{S}$ and their bearing on exsolution textures in ores. Econ. Geol. 59: 1241-1269.

Carpenter, A. B. (1967) Mineralogy and petrology of the system $\mathrm{CaO}-\mathrm{MgO}-\mathrm{CO}_{2}-\mathrm{H}_{2} \mathrm{O}$ at Crestmore, California. Am. Mineral. 52: 1341-1363.

Coetzee, G. L. (1963) Carbonatites of the Karema Depression, Western Tanganyika. Trans. Geol. Soc. South Africa 66: 283-340.

Goldsmith, Julian R. (1960) Exsolution of dolomite from calcite. J. Geol. 68: 103-109.

Goldsmith, Julian R. and Graf, Donald L. (1958) Structural and compositional variation in some natural dolomites. J. Geol. 66: 678-693.

Goldsmith, Julian R., Graf, Donald L. and Joensuu, Orva I. (1955) The occurrence of magnesian calcites in nature. Geochim. Cosmochim. Acta 7: 212-230.

Goldsmith, Julian R. and Heard, Hugh C. (1961) Subsolidus phase relations in the system $\mathrm{CaCO}_{3}-$ $\mathrm{MgCO}_{3}$. J. Geol. 69: 45-74.

Goldsmith, Julian R. and Newton, Robert C. (1969) $\mathrm{P}-\mathrm{T}-\mathrm{X}$ relations in the system $\mathrm{CaCO}_{3}-\mathrm{MgCO}_{3}$ at high temperatures and pressures. Am. J. Sci. 267-A: $160-190$.

Graf, Donald L. and Goldsmith, Julian R. (1955) Dolomite-magnesian calcite relations at elevated temperatures and $\mathrm{CO}_{2}$ pressures. Geochim. Cosmochim. Acta 7: 109-128.

Harker, R. I. and Tut'tle, O. F. (1955) Studies in the system $\mathrm{CaO}-\mathrm{MgO}-\mathrm{CO}_{2}$. Part II, limits of the solid solution along the binary join $\mathrm{CaCO}_{3}-\mathrm{MgCO}_{3}$. Am. J. Sci. 253: 274-282.
HeInrich, E. WM. (1966) The geology of carbonatites. Rand McNally \& Co., Chicago.

Ioffe, L. I. (1972) Stability of natural magnesian calcite. Dokl. Akad. Nauk SSSR 203: 132-134.

Ioffe, L. I., Krylov, I. N. and Nikitina, L. P. (1973) Magnesial calcites as indicators of temperature of the metamorphism (exemplified by Archean complex in Baykal region). Int. Geol. Rev. 15: 416-427.

Kononova, V. A. and Tarashchan, A. N. (1970) Thermoluminescence of carbonates from carbonatites. Int. Geol. Rev. 12: 272-280.

Puustinen, Kauko (1971) Geology of the Siilinjärvi carbonatite complex, eastern Finland. Bull. Comm. Geol. Finlande 249.

- (1972) Richterite and actinolite from the Siilinjärvi carbonatite complex, Finland. Bull. Geol. Soc. Finland 44: 83-86.

- (1973) Tetraferriphlogopite from the Siilinjärvi carbonatite complex, Finland. Bull. Geol. Soc. Finland 45: $35-42$.

QuON, SHI HAUNG (1965) Geochemistry and paragenesis of carbonatitic calcites and dolomites. Ph.D. thesis, Univ. Michigan, Ann Arbor.

Quon, Shr H. and Heinrich, E. WM. (1966) Abundance and significance of some minor elements in carbonatitic calcites and dolomites. Min. Soc. India, I.M.A. volume: $29-36$.

VEEN, A. H. VAN DER (1965) Calcite-dolomite intergrowths in high-temperature carbonate rocks. Am. Mineral. 50: $2070-2077$.

Manuscript received, February 26, 1974. 